\title{
Program EducAtivo: physical activity as a health education strategy
}

\author{
Programa EducAtivo: a atividade física como estratégia de educação em saúde
}

\section{AUTHOR'S \\ Ronailde Braga Guerra ${ }^{1}$ (D) \\ Alex Antônio Florindo 2 (D) \\ Jaqueline Freitas de Oliveira $\mathrm{Neiva}^{3}$ (D) \\ Douglas Roque Andrade 2 (D) \\ 1 University of São Paulo; School of Arts, Sciences and Humanities, São Paulo, São Paulo, Brazil \\ 2 University of São Paulo; School of Arts, Sciences and Humanities; Group of Epidemiological Studies and Research in Physical Activity and Health, São Paulo, São Paulo, Brazil \\ 3 University of São Paulo; School of Arts, Sciences and Humanities; School of Physical Education and Sports, São Paulo, São Paulo, Brazil.}

\section{CORRESPONDING}

Ronailde Braga Guerra

ronailde.braga@usp.br

Rua Arlindo Bettio, 1000

Vila Guaraciaba, São Paulo, São Paulo, Brazil. CEP: 03828-000.

DOI

$10.12820 /$ rbafs. $23 \mathrm{e} 0056$

\section{(cc) BY-NC-SA}

This work is licensed under the Creative Commons Attribution-NonCommercial-ShareAlike 4.0 International License

\begin{abstract}
This study aimed to describe the transition from the intervention protocols of the research project entitled "Active Environment" to the conception of the university extension program known as "EducAtivo". Considering the complexity of the context of physical activity promotion and the need to understand its processes, this manuscript justifies itself as it addresses such need by reporting the procedures adopted along the extension program implementation. The result of this transition is the current proposal of EducAtivo, aimed at creating opportunities for health experiences and reflection, using physical activities/body practices as a health education strategy, apart from approaching related topics such as healthy eating. With an itinerant design, this program implements its activities in social spaces, bringing the university closer to the community. Furthermore, EducAtivo welcomes students from different courses, fostering qualification for multi-professional work, since this is fundamental in the health field. Fundraising has been sought, aiming to improve and increase the program.
\end{abstract}

Keywords: Exercise; Health promotion; Community-institutional relations.

RESUMO

Objetivou-se descrever a transição dos protocolos de intervenção da pesquisa "Ambiente Ativo" à construção do programa de extensão universitária "EducAtivo". Considerando a complexidade do cenário da promoção da atividade física e a necessidade de compreensão de seus processos, este manuscrito se justifica à medida que vai ao encontro de tal necessidade ao relatar os procedimentos adotados no decurso da implementação do programa de extensão. O resultado dessa transiçẫo consiste na atual proposta do EducAtivo, que tem por objetivo criar oportunidades à vivência e reflexão em saúde, lançando mão das atividades físicas/práticas corporais como estratégia de educação em saúde, além de abordar temáticas correlatas, como alimentação saudável. De caráter itinerante, o programa realiza atividades em espaços sociais, aproximando a universidade da comunidade e recebe estudantes de diferentes cursos, fomentando a capacitação para atuação multiprofissional, fundamental no campo da saúde. Busca-se aprimorar e ampliar o programa com a captação de recursos.

Palavras-chave: Exercício; Promoção da saúde; Extensão comunitária.

\section{Introduction}

The pandemic of physical inactivity and its repercussions for society ${ }^{1-3}$ have included the theme of physical activity (PA) in the agenda of public policies worldwide. Not coincidentally, the Global Strategy on Diet, Physical Activity and Health ${ }^{4}$ was proposed in 2004. In Brazil, PA has been included in the public sphere since 2000 by the Rede Agita Brasil $1^{5}$ and consolidated with the Brazilian Physical Activity Network in $2005^{6}$. Such context, added to the results of studies on the effectiveness of PA interventions, which indicated little change in populational PA levels ${ }^{7}$, represents a challen- ge for the planning and implementation of evidence-based practices. In this context, in 2010, the Group of Epidemiological Studies and Research in Physical Activity and Health (GEPAF) conducted the research project entitled "Assessment of Interventions for the Promotion of Physical Activity in the Unified Health System through the Family Health Strategy", whose actions were known as "Active Environment" ${ }^{\text {. The re- }}$ sults indicated that health education interventions are more effective for the maintenance of $\mathrm{PA}$ practice in the post-intervention period, compared to interventions of supervised exercises ${ }^{9}$. 
The experiences accumulated during interventions, combined with the challenge of uniting the knowledge generated by scientific production and the development of health promotion practices through $\mathrm{PA}^{8}$, caused the GEPAF to create the university extension program known as "EducAtivo"(Active Education). The present study describes the process of transition of the protocol used in the research on EducAtivo practices.

\section{Active Environment Research: historical context}

In 2007, the GEPAF performed a home-based survey in the district of Ermelino Matarazzo, in East São Paulo, revealing that $68.7 \%$ of the adult population did not practice PA in their leisure time, $14.3 \%$ did not walk as a means of transport and $47.1 \%$ did not meet the recommendation of 150 minutes of PA practice/week ${ }^{8,10}$. In view of this diagnosis, between 2010 and 2012, the GEPAF implemented interventions for PA promotion in the Sistema Único de Saúde (SUS - Unified Health System) through the Estratégia de Saúde da Família (ESF - Family Health Strategy). They were known as the Ambiente Ativo (Active Environment) ${ }^{8}$, developed with the Superintendence of Health and Sports of the Regional City Hall of Ermelino Matarazzo, funded by the São Paulo Research Foundation (FAPESP).

One of the strategies compared interventions with adults and elderly individuals, who are SUS users, apparently healthy and insufficiently active during leisure time and/or transport. A total of three groups were formed, including approximately 50 participants in each one, originated from distinct Unidades Básicas de Saúde (UBS - Primary Care Centers), one of which is the control group while the other two are intervention groups. During 12 months, one of the groups participated in a supervised exercise program (three sessions of 60 minutes per week) in the facilities of the School of Arts, Sciences and Humanities of the University of São Paulo (EACH-USP), while the other group participated in a health education program with 16 meetings of 120 minutes each, four of which were weekly, two were biweekly and ten were monthly, all held in community spaces ${ }^{9,11}$. The results pointed to an increase in the PA level in both groups when the interventions were concluded. However, better results were found for maintenance of PA levels six months after the intervention in the health education group ${ }^{9}$, thus becoming a potential for the improvement of PA promotion actions in similar contexts. The end of this research project did not mean the purpose of encouraging the exchange of knowledge and skills among actors who promote PA in Ermelino Matarazzo was achieved. Thus, in 2013, aiming to continue the Active Environment interventions, which started as a research protocol, the university extension program known as EducAtivo was created.

\section{Program EducAtivo development}

\section{First steps}

Following the steps taken by the Active Environment interventions, the first EducAtivo intervention was conducted in partnership with a UBS. At first, an 12-month intervention was proposed, including physical activity sessions in the EACH-USP facilities, intertwined with meetings to discuss the themes from the health education group, thus mixing the protocols of both interventions. This design occurred by convenience, due to the infrastructure provided by the $\mathrm{EACH}-$ -USP. In September 2013, different areas of the campus were closed due to environmental problems and, as a result, the program was discontinued. This situation caused the campus to be closed in the first semester of $2014^{12}$, being subsequently reopened in August of the same year.

\section{Rethinking the intervention model}

The loss of space associated with the period of academic and administrative reorganization of the EACH-USP forced the program to be suspended until the second semester of 2015. As the context at that time did not promote the initial format proposed for the EducAtivo, changes to enable its continuity were required. Additionally, human and financial resources for the program were reduced, compared to research, something that had already been noticed in the beginning of the extension activities. Research included resources for educational materials and interviewers, apart from the Nutrition, Physical Education, Psychology and Medicine professionals who developed and implemented this intervention. In the EducAtivo, the resources were reduced to one Physical Education professional not exclusively dedicated to the program and one volunteer trainee.

In this context, the proposal was reformulated, drawing closer to the health education group protocol. It functioned in the UBS and social spaces around the EACH-USP, although with different intervention 
times: the 16 meetings spread across 12 months of protocol were concentrated in ten weekly meetings. Another change was associated with the EducAtivo team, which included the participation of students from several EACH-USP courses through the university's Programa Unificado de Bolsas (PUB - Unified Scholarship Program), when activities with the UBS (with which the program began in 2013) were resumed.

\section{Reality shaping the protocol}

In the field, the demands made by those cared for, the structural conditions of intervention spaces and the limited resources shaped the thematic meetings of the original protocol.

In view of the fact that certain protocol themes were implemented by specialists, their absence in the EducAtivo program led to the adaptation or exclusion of such themes. As an example, the meeting on stress management, guided by a psychologist during the study, was excluded, although the theme is dealt with when brought up. Meetings on eating habits, conducted by nutritionists at the time, were reorganized according to instructions from the new edition of the Dietary Guidelines for the Brazilian Population, released in $2014^{13}$.

Without interviewers to select insufficiently active individuals - the research target population - the project was promoted by the UBS and through the distribution of printed material, which mainly attracted those who were already engaged in PA practice and saw the project as an opportunity to increase/qualify their practice. This context led to an increase of at least $50 \%$ in the length of time of physical activities/body practices of meetings, differing from the original proposal ${ }^{9}$. Moreover, this caused discussions to follow a different path: acute physiological changes of exercises, perceived and expressed by participants during and after their practice, guiding the discussion on the importance of PA for health in biological terms.

After the first interventions, the duration of meetings was reduced from 120 to 90 minutes, as the population cared for, most of whom were females, performed other activities, usually related to home and family care, that concurred with the period when the program was offered (mornings). The current program schedule, resulting from the exclusion, combination or division of themes, is shown in Figure 1. Its development considered the main goal of the original intervention and the opinions of participants and students involved.
Figure 1 - Description of the Program EducAtivo.

\begin{tabular}{|c|c|}
\hline Meeting & Proposed activity \\
\hline & $\begin{array}{l}\text { Group dynamics to integrate participants and discuss the } \\
\text { concept of physical activity }\end{array}$ \\
\hline 1. & Project presentation (history, objective and timetable) \\
\hline 2. & $\begin{array}{l}\text { Physical activity for flexibility: workshop and discussion } \\
\text { according to the physical perception of practice }\end{array}$ \\
\hline \multirow[t]{2}{*}{3.} & $\begin{array}{l}\text { Physical practice correlated to the previous theme/Group } \\
\text { development of the class }\end{array}$ \\
\hline & $\begin{array}{l}\text { Classification of foods according to the Dietary Guidelines for } \\
\text { the Brazilian Population (GAPB) }\end{array}$ \\
\hline 4. & $\begin{array}{l}\text { Physical activity for aerobic capacity: workshop and discussion } \\
\text { according to the physical perception of practice }\end{array}$ \\
\hline \multirow[t]{2}{*}{5.} & $\begin{array}{l}\text { Physical practice correlated to the previous theme/Group } \\
\text { development of the class }\end{array}$ \\
\hline & Presentation of “Ten Steps to Healthy Diets" - part 1 \\
\hline 6. & $\begin{array}{l}\text { Physical activity for strength: workshop and discussion } \\
\text { according to the physical perception of practice }\end{array}$ \\
\hline \multirow[t]{2}{*}{7.} & $\begin{array}{l}\text { Physical practice correlated to the previous theme/Group } \\
\text { development of the class }\end{array}$ \\
\hline & $\begin{array}{l}\text { Presentation of "Ten Steps to Healthy Diets" - part } 2 \text { and } \\
\text { distribution of pocket GAPB* }\end{array}$ \\
\hline \multirow[t]{2}{*}{8.} & Physical activity for balance motor skill \\
\hline & $\begin{array}{l}\text { Completion of the "Life Wheel" instrument, discussion of the } \\
\text { health concept and distribution of the GAF** }\end{array}$ \\
\hline \multirow[t]{2}{*}{9.} & Assessment of the project by participants using a questionnaire \\
\hline & $\begin{array}{l}\text { Physical activity or practice selected by participants/Review of } \\
\text { contents and workshops }\end{array}$ \\
\hline 10. & $\begin{array}{l}\text { Extra meeting (for eventual changes to the timetable or specific } \\
\text { group needs) }\end{array}$ \\
\hline
\end{tabular}

* Illustrated folder of the "Ten Steps to Healthy Diets" from the GAPB; ** Physical Activity Guidelines (illustrated folder with a summary of physical capacities and self-care).

The vulnerability of the network of project partners due to changes in the municipal administration and Social Organizations that manage the health equipment led to the search for new partnerships and to the EducAtivo implementing its activities in NGOs, libraries, parks and condominiums, apart from seeking partnerships with institutions from the Ermelino Matarazzo Network of Physical Activity ${ }^{14}$.

\section{Program's general characterization}

EducAtivo was created to provide PA to individuals who are insufficiently active during leisure time, aiming to increase the PA level of the population in Ermelino Matarazzo. Guided by this objective, the first interventions were performed practically according to the original protocol. However, the program implementation in the field and the observation that the individuals cared for differed from the research target population and that reaching them would not be possible with the available 
resources led to a period of replanning and the resulting change of direction of the program. At this stage, the understanding that the program's indicators and capacity for service provision and assessment did not meet its objective was essential for the definition of its current objective - to create opportunities for reflection and experiences in health - including services provided to students and participants. The current logical model shows this, as it guides the team's actions (Figure 2).

The implementation of EducAtivo begins with the partnership with the space manager - when the history, proposal and timetable are shown with the support of an illustrated folder - and with its promotion through posters and flyers distributed in the area and its surroundings. Initially printed with EACH-USP resources, most of this material is now funded with the resources obtained from the 2nd Public Notice of the Santander/USP/FUSP for Public Policies and Fundamental Rights. This was also the source of funds for the colored print of the educational materials entitled "Physical Activity Guidelines" - which includes information about physical skills and self-care for PA practice - and "Ten Steps to Healthy Diets" - which covers a summary of information from the Dietary Guidelines for the Brazilian Population - developed by the team from the demands that arose in the field.

There is not a fixed number of vacancies, as they are made available according to the space provided. However, a minimum of 15 participants has been established for the program to begin. Adults and elderly individuals are the target population, regardless their PA level. In addition to the difficulty to invite

Figure 2 - Logical model of the EducAtivo Program.

\begin{tabular}{|c|c|c|c|c|}
\hline Resource & Activity & Product & Result & \\
\hline $\begin{array}{l}\text { - Students (trainees and } \\
\text { scholarship recipients) } \\
\text { Material resources: } \\
\text { - Locations for intervention } \\
\text { - Educational and office } \\
\text { materials }\end{array}$ & $\begin{array}{l}\text { - Continuous planning and } \\
\text { assessment } \\
\text { - Team training } \\
\text { - Meetings with stakeholders } \\
\text { - Diagnosis of interest and } \\
\text { the area } \\
\text { - Project promotion } \\
\text { - Rounds of conversation } \\
\text { - Dialogue-based } \\
\text { expository classes } \\
\text { - Production and distribution } \\
\text { of educational material } \\
\text { - Workshops and physical } \\
\text { activities/ } \\
\text { body practices } \\
\text { - Group dynamics about } \\
\text { healthy eating }\end{array}$ & $\begin{array}{l}\text { - Number of locations served } \\
\text { - Program website (under } \\
\text { construction) } \\
\text { - Database of workshops } \\
\text { (description of activities - under } \\
\text { construction) } \\
\text { - Educational material } \\
\text { developed (pocket GAF and } \\
\text { GAPB*) } \\
\text { - Number of hours and services } \\
\text { provided/participants served }\end{array}$ & $\begin{array}{l}\text { Population: } \\
\text { - Identification of physical activity programs in } \\
\text { the area } \\
\text { - Identification of the environment built for } \\
\text { physical activity } \\
\text { - Acquisition of the ten steps of the GAPB } \\
\text { - Acknowledgement of one's sedentary behavior } \\
\text { - Improvement of one's knowledge about physical } \\
\text { capacity } \\
\text { - Change in perception of PA and HD** } \\
\text { Medium term: } \\
\text { Students: } \\
\text { - Qualification to mediate program activities } \\
\text { Population: } \\
\text { - Adherence to the physical activity programs } \\
\text { and/or use of public spaces } \\
\text { - Identification of physical capacities } \\
\text { - Improvement/ maintenance of physical activity } \\
\text { practice } \\
\text { - Reduction of sedentary behavior } \\
\text { - Acknowledgment of the healthy eating concept } \\
\text { and of the ten steps to healthy diets } \\
\text { Long term: } \\
\text { Students: } \\
\text { - Professional qualification to work in health } \\
\text { education } \\
\text { Population: } \\
\text { - Incorporation of physical activity and healthy } \\
\text { eating in one's lifestyle }\end{array}$ & 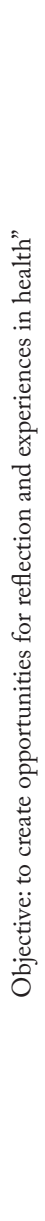 \\
\hline
\end{tabular}

Influencing factors

Availability of scholarships; location for intervention; weather; number of participants; technical knowledge; service hours.

* Physical Activity Guidelines = illustrated folder with a summary of physical capacities and self-care and pocket GAPB = illustrated folder of the "Ten Steps to Healthy Diets"; ** Physical Activity (PA) and Healthy Diet (HD). 
insufficiently active participants, many of those who already practiced PA invariably did so without basic care (hydration; warm-up; proper diet) or due to medical guidance without, however, understanding the benefits of the practice for their health condition. This context led the program to be conducted according to the perspective of functional health literacy ${ }^{15}$, touching on questions about self-care regarding PA practice, its acute and chronic physiological changes and, when relevant, the resulting effects on the treatment of certain non-communicable chronic diseases.

On the first day, recreational activities function as strategies for the interaction between participants and the program team and triggers for the discussion of the concept of PA. The presentation of the history, objective and timetable to the public also occurs on the first day, aiming to lay the foundation for the program's itinerant model and to emphasize the co-responsibility in the implementation and effectiveness of the intervention. Although the program has an educational sequence, each meeting is designed to be independent, due to the variation in the frequency of participants. During the experiences, participants are encouraged to pay attention to their body and the feelings/sensations that arise with the exercises. Reports on their body perception serve as the foundation of dialogue-oriented expository lessons about physical skills and capacities. Whenever possible, guided walks and visits to public equipment in parks, squares and outdoor gyms are performed. A total of approximately 15 hours of in-person activities with each group are conducted (1x/week; 90 minutes/day; 9 to 10 weeks).

Concurrently with the activities with the population, training courses are performed with the students received in the program, including activities such as reading, videos and practical laboratory for fieldwork. They bring practices such as capoeira, yoga, senior dance and others, apart from specific discussions, thus collaborating to the diversity of activities. However, this context causes the program to be unstable due to the team's rotation, mainly including undergraduate students who already total 20 individuals, among which are scholarship recipients, trainees and volunteers.

\section{Final considerations}

To begin a physical activity program guided by an intervention protocol and based on research results has certainly promoted the development of its foundations. However, maintaining the initial proposed model as a university extension program was impossible due to the difficulties found in terms of available resources. After three years of uninterrupted work, this program has gained experience and taken advantage of this for its own development. EducAtivo has recently received funds from the university's Programa Aprender na Comunidade (Learning in the Community Program), which supports extramural activities developed by students in their professional practice and whose resources are used to improve the services and increase the impact of physical activity promotion actions in Ermelino Matarazzo.

\section{Conflicts of interest}

The authors declare no conflict of interest.

\section{Author contributions}

Guerra RB participated in the manuscript design, data collection, and text writing and review. Florindo AA contributed to the critical text review. Neiva JFO contributed to the critical text review. Andrade DR participated in the manuscript design, critical review and approval of the final version.

\section{Acknowledgments}

Authors would like to thank all professionals, students, partners and participants who help us make EducAtivo a reality.

\section{References}

1. Kohl HW, Craig CL, Lambert EV, Inoue S, Alkandari JR, Leetongin $\mathrm{G}$, et al. The pandemic of physical inactivity: global action for public health. Lancet. 2012;380(9838):294-305.

2. Andersen LB, Mota J, Di Pietro L, Lee I, Shiroma E, Lobelo $\mathrm{F}$, et al. Update on the global pandemic of physical inactivity. Lancet. 2016;0(0):219-29.

3. Ding D, Lawson KD, Kolbe-Alexander TL, Finkelstein EA, Katzmarzyk PT, van Mechelen W, et al. The economic burden of physical inactivity: a global analysis of major noncommunicable diseases. Lancet. 2016;388(10051):1311-24.

4. Organização Mundial da Saúde. Estratégia global em alimentação saudável, atividade física e saúde. Genebra: WHO; 2004;1-23. [citado 2018 jun 11]. Disponível em: http://189.28.128.100/nutricao/docs/geral/ebPortugues.pdf.

5. Brasil. Ministério da Saúde. Programa Nacional de Promoção da Atividade Física "Agita Brasil": atividade física e sua contribuição para a qualidade de vida. Rev Saude Publica. 2002;36(2):254-6.

6. Amorim TC, Knuth AG, Cruz DKA, Malta DC, Reis RS, Hallal PC. Descrição dos programas municipais de promoção da atividade física financiados pelo Ministério da Saúde. Rev Bras Ativ Fís Saúde. 2013;18(1):63-74.

7. Parra MPH DC, Brownson RC, Heath GW, Parra DC, Sarmiento OL, Bo Andersen L, et al. Evidence-based intervention in physical activity: lessons from around the world. Lancet. 2012;380(380):272-81. 
8. Andrade D, Costa E, Ribeiro E, Salvador E, Garcia L, Florindo A. Do diagnóstico à ação: A experiência da pesquisa Ambiente Ativo na promoção da atividade física em Ermelino Matarazzo, na zona leste de São Paulo, SP. Rev Bras Ativ Fís Saúde. 2012;17(1):235-8.

9. Ribeiro EHC, Garcia LMT, Salvador EP, Costa EF, Andrade DR, Latorre MRDO, et al. Avaliação da efetividade de intervenções de promoção da atividade física no Sistema Único de Saúde. Rev Saude Publica. 2017;51(56):1-12.

10. Florindo AA, Salvador EP, Reis RS, Guimaraes VV. Percepção do ambiente e prática de atividade física em adultos residentes em região de baixo nível socioeconômico. Rev Saude Publica. 2011;45(2):302-10.

11. Salvador EP, Ribeiro EH, Garcia LM, Andrade DR, Guimaraes VM, Aoki MS, et al. Interventions for physical activity promotion applied to the primary healthcare settings for people living in regions of low socioeconomic level: study protocol for a non-randomized controlled trial. Archives of Public Health. 2014;72:8.
12. Agência Brasil. Por contaminação, USP Leste é interditada a partir desta quinta. Carta Capital. 2014. [citado 2018 jun 18]. Disponível em: https://www.cartacapital.com.br/sociedade/ usp-leste-e-interditada-por-solo-contaminado-8415.html.

13. Brasil. Ministério da Saúde (MS). Guia Alimentar para a População Brasileira. 2a ed. Brasília: MS; 2014. 156 p. [citado 2015 setembro 17].Disponível em: http://bvsms. saude.gov.br/bvs/publicacoes/guia_alimentar_populacao_ brasileira_2ed.pdf.

14. Andrade DR, Garcia LMT, Perez DCP. Colaborações locais para a promoção da atividade física: uma análise de rede. Cad. Saúde Pública. 2018;34(10):e00127517.

15. Passamai M da PB, Sampaio HADC, Dias AMI, Cabral LA. Letramento funcional em saúde: reflexões e conceitos sobre seu impacto na interação entre usuários, profissionais e sistema de saúde. Interface (Botucatu). 2012;16(41):301-14.

Received on: 30/01/2019

Approved on: 25/04/2019

\section{Quote this article as:}

Guerra RB, Florindo AA, Neiva JFO, Andrade DR. Programa EducAtivo: a atividade física como estratégia de educação em saúde. Rev. Bras Ativ Fís Saúde. 2018;23:e0056. DOI: 10.12820/rbafs.23e0056 